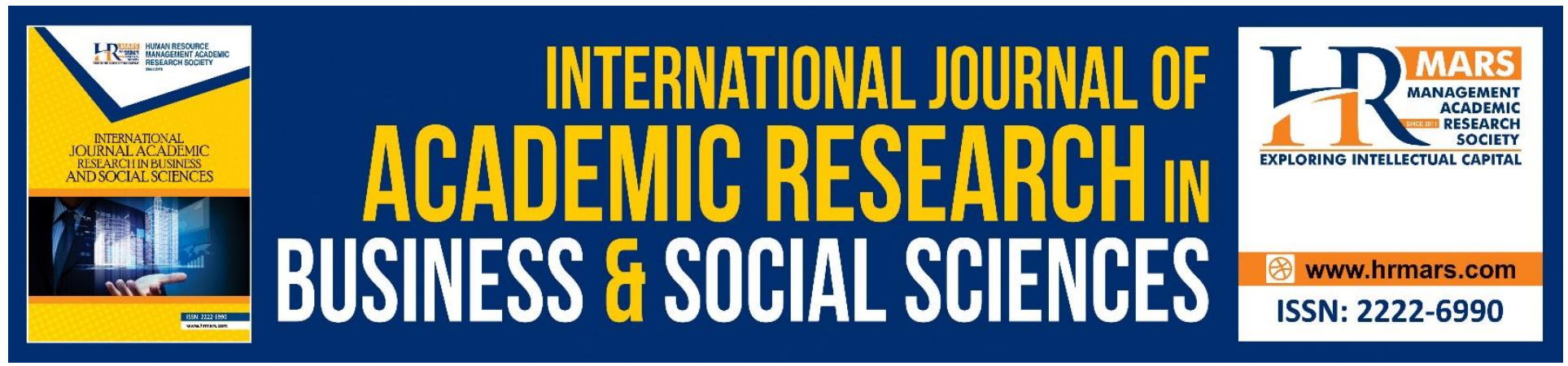

\title{
Management of Government Information in the Era of Electronic Government: Where we are?
}

Junaidah Binti Rosliy, Norhayati Hussin

To Link this Article: http://dx.doi.org/10.6007/IJARBSS/v8-i9/4644

DOI: $\quad 10.6007 /$ IJARBSS/v8-i9/4644

Received: 03 August 2018, Revised: 29 August 2018, Accepted: 29 Sept 2018

Published Online: 20 October 2018

In-Text Citation: (Rosliy \& Hussin, 2018)

To Cite this Article: Rosliy, J. B., \& Hussin, N. (2018). Management of Government Information in the Era of Electronic Government: Where we are? International Journal of Academic Research in Business and Social Sciences, 8(9), 630-638.

Copyright: (C) 2018 The Author(s)

Published by Human Resource Management Academic Research Society (www.hrmars.com)

This article is published under the Creative Commons Attribution (CC BY 4.0) license. Anyone may reproduce, distribute, translate and create derivative works of this article (for both commercial and non-commercial purposes), subject to full attribution to the original publication and authors. The full terms of this license may be seen at: http://creativecommons.org/licences/by/4.0/legalcode

Vol. 8, No. 9, September 2018, Pg. 630 - 638

Full Terms \& Conditions of access and use can be found at http://hrmars.com/index.php/pages/detail/publication-ethics 


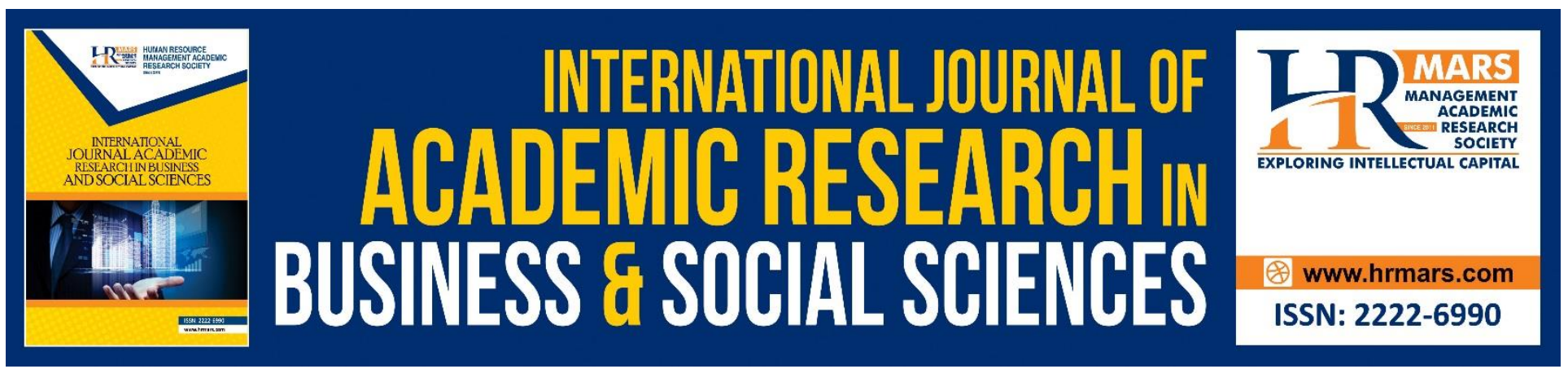

\title{
Management of Government Information in the Era of Electronic Government: Where we are?
}

\author{
Junaidah Binti Rosliy, Norhayati Hussin \\ Faculty of Information Management, Universiti Teknologi MARA, UiTM Selangor, Malaysia
}

\begin{abstract}
The implementation of electronic government by Malaysia government was started since the Malaysia awarded Multimedia of Science Coridor (MSC). In order to ensure the successfulness of the transition, it is important for the government to identify and resolve the various issues exist in electronic government to avoid falling behind. This paper discusses the issues regarding the development of government information management in the era of electronic government in Malaysia. Rapid change of new technology enhancing demand for the government performance as a whole especially the process of manage government information either federal or state level and making the information gather accessible and available to all citizen through. How should our electronic government go about this and make it success? This paper presents a strategic options to government in manage information that could be widely relevant to citizens.
\end{abstract}

Keywords: Government Information, Information Management, Electronic Government

\section{INTRODUCTION}

Nowadays, government collects a variety of sorts and forms of information that play as a main part in daily tasks. Government information is the most important source that has a big role as a guideline in implement various government activities, programs, projects, activities in ministries, departments and agencies. Government information exists in many forms. It can be in printed (books, periodicals, magazines, reports, papers, technical reports, legal resources, maps, posters, kits and pamphlets, brochures, minutes meeting), non-printed (video recording, film, CD-ROMs, DVD-ROMs, DVDs, audio and video cassettes), electronic media and digital resources (eBooks and other online collections). Government information has a big influence and impact for develop country that has first-class minds citizens. Government information records all the process of formulating a government policy, law, government administrative process, government programs and projects that have a huge implication on the development of people and nation as a whole. Government information can be described as a memory of the state, state and organization. Therefore the management of government information in term of acquisition, documentation, storage, conservation and dissemination of government information need to be effectively and efficiently organize for current and future generation's references. In the era of government transformation towards the advanced change of 
INTERNATIONAL JOURNAL OF ACADEMIC RESEARCH IN BUSINESS AND SOCIAL SCIENCES Vol. 8, No. 9, Sept. 2018, E-ISSN: 2222-6990 @ 2018 HRMARS

electronic government services (information, transactions) via electronic means, government information need to fully use by Malaysian citizens at anywhere and anytime for whatever reason.

\section{IMPORTANT OF GOVERNMENT INFORMATION}

In the era of electronic government, government give more focused on the efficiency of government departments and agencies in delivering quality services to the people. The ability in delivering good services, make a right decision making and executing quality is dependent on the extent to which the needed information can be exist, stored, accessed and used. Most of the information produced is contained in the records maintained by a department and agency. Challenge toward transforming the civil service, the Government has implemented various initiatives and projects through the responsible utilization and enhancement of information and communication technology (ICT), which serves as a strategic enabler towards services beyond the expectation of the people. Under electronic government initiatives, there a several main project that has been implementing such as Blue Ocean Strategy national or National Blue Ocean Strategy (NBOS) that change the paradigm employed in silo to strategic cooperation across agencies, Rural Transformation Centre (RTC), Urban Transformation Centre (UTC), Human Resources Management Information System (HRMIS), Electronic Services Delivery (EServices), Electronic Labour Exchange (ELX), Electronic Procurement (eP), Project Monitoring Services (PMS) and many more have been successfully carried out using the new approach with reasonable cost and provide added value.

Generally, government information are those issued or published held by authority of government bodies at all levels either international, national, federal, provincial/territorial, local governmental bodies and intergovernmental bodies. Each year, government at federal and state level publish hundreds of information in term of publication such as reports, newsletters and many more either in printed, non-printed or via online. Government information covers wide range of subjects that was classified as follows:

a) Information related to national administration

Publication published by the various ministries, government departments and Government agencies at the Federal and State levels such as government policies, annual reports, reports of research results, project proposal or Government programs, directives and circulars, Government policy, manuals and guidelines, directory of civil servants and many more.

b) Information relating to congress and legislation

Publications includes reports of parliamentary debates, parliamentary paper, Act and enactment, Congressional bill, legislative proposals, directory, Constitution of the country, policy papers and a range of other issues related to law of the country.

c) Information concerning judicial

Publication covers a wide variety of information related to Case Law, Courts and Judicial Resources such as the Court of trial cases, the decision of the judge, court travel procedures and so on.

d) Research results associated government published by the researchers findings and publication among academician, government leader and civil servants figures related to the 
INTERNATIONAL JOURNAL OF ACADEMIC RESEARCH IN BUSINESS AND SOCIAL SCIENCES

Vol. 8, No. 9, Sept. 2018, E-ISSN: 2222-6990 @ 2018 HRMARS

issues that occurred within the Government such as the development, politics, social, economic and other subject and field.

\section{MANAGEMENT OF GOVERNMENT INFORMATION}

In the era of information age, the important of government information as evidence of action, policies, expenditure, transactions, precedents, rights and entitlements are fully understand by every public sector policy maker, auditor, court official as well as fraud investigator. A part from that government information are useful to all citizen in order to show their rights such as for land rights or rights in court. Therefore it is necessary to have knowledge and skill to find, use and trust all the information published by government. Unfortunately, in many countries, government information is difficult to locate and trust.

Effectively and efficiently manage of government information will be able to provide clear and reliable evidence in order to show of what the government has plan, promise, done, what kind of services that has been provide to the citizen, as well as how public fund has been spent. Through all this, it will make government more open and acceptable by the citizen. Meanwhile, if the government information are not manage properly, it contribute to the misleading of national evidence that contribute to the opportunities of corruption, manipulation, fraud as well as citizens unable to claim their rights and entitlements. A part from that the process of planning and monitor policies and services become more difficult and make government information close to the public. Poor management of records in public service delivery will contribute to the question of integrity of public sector and people lost their respect to the government.

Successful open government will ensure that government information is reliable, accurate, accessible, usable and authentic for as long as it may be needed. This aspect of management mainly covers the process of creation, usage, store, disposal and access to information. In developing commitments in managing government information, countries should clearly highlight how information management will serve to make government more open.

To ensure that government information is managed in an efficient and orderly manner, the following aspects have been identified as follow:

a) Tracing and Collecting

Act as a custodian of the national heritage, National Archives of Malaysia (NAM) and National Library of Malaysia (NLM) responsible with the information management process as a whole. As government agencies that are involved directly with electronic records, these two agencies reacted in proactively manner in collecting and storing government information. National Archives Act 1966 that was amended and passed in 2003, National Archives of Malaysia (NAM) have a mandate in governing the management of electronic records from creation till disposition in the public sector.

A part from that all employees in federal and state government are responsible for the records they create and maintain. All employees can make a major contribution to good records management in their agencies on a daily basis through effective cross-boundary partnerships. 
INTERNATIONAL JOURNAL OF ACADEMIC RESEARCH IN BUSINESS AND SOCIAL SCIENCES Vol. 8, No. 9, Sept. 2018, E-ISSN: 2222-6990 @ 2018 HRMARS

b) Easy access storage

Ideally, the collection of government information should be stored locally under one hub. National archive and national library are agencies that play a big responsibility in delivery, storage, and give references services of government information. Federal and state government documents become an important and unique part of library and archives holdings. With accumulated and availability of all government information in the national archives and national library, the process of documentation government information performed accordingly to the national standards.

Based on the Jamil, (2007), started from 2006, NAM was give a mandate by a government to take the lead on electronic records management systems and today, NAM has produced six guidelines and policies for electronic records management that necessary to follow which is:

(1) Electronic records management policy.

(2) General guidelines of electronic records management.

(3) Guidelines of electronic records management - structured environment. (4) Guidelines of electronic records management - unstructured environment. (5) Guidelines of electronic records management - web environment.

(6) Electronic records management specification. A part from that, Malaysia government under Unit Pemodenan Tadbiran dan Perancangan Pengurusan Malaysia (MAMPU) was introduce one official portal that act as single gateway or hub for information and services offered online by government. The portal known as MyGovernment Online Services Portal (www.malaysia.gov.my) facilitates citizen to access any kind of government information and online services at anytime and anywhere. According to the MAMPU, until now, this single gateway was provide links to more than 1,200 government portals and websites using navigation method which assist and guide in search relevant government information and services with the hope to improve the quality of government service delivery in term of Increase customer satisfaction, government services being more transparent, competitive and competent and improving the accessibility of online services to government service.

Study conducted by Mokhtar \& Zawiyah (2009) has showed that the development of electronic records management in Malaysia government as well as acceptance level for electronic records management in Malaysia is very encouraging. Nowadays, government both federal and state level have develop their own electronic records management to store government information and make it available to the public. Electronic record management leads to significant improvement of daily task in government operation that can increase quality of public service delivery to the public at large. However, the result finding of the study showed that Implementation of electronic records management policy is not possessed by all government departments and the number of organization carrying out electronic records management without any policy in place is frightening. 
c) Preservation and Digitization

Preservation is very important aspects that need to be focus in record management process especially for government information in order to ensure the accessibility over a period of time. National Archives Act of 2003 under National Archive of Malaysia (NAM) becomes a guideline in managing records management in the public sector especially related with the preservation. This is important in order to increased government support for its records management work and to improve its government record preservation work. Information and records custodians such as archives and libraries traditionally offer long-term public access to significant government information in various formats and have big responsibilities to provide special care and treatment for government records with the purpose to protect and save the intellectual heritage as well as cultural history of the nation.

Kootshabe, Josephine \& Mnjama. (2014) was highlight the issued regarding developments of preservation code of ethics in term of storage facilities, use and handling, control of conditions such as temperatures, relative humidity and paper quality for creating records conservation treatment and disaster preparedness. However, they believe with the good collaboration between academic institutions, private and government agencies, records management especially for government information has the potential to succeed. There are two main aspect in preservation management first is preventive preservation which is all activities done to ensure a record does not deteriorate and restorative preservation meanwhile restorative preservation refers to treatment of a damaged record.

Digitization is a one aspect of record preservation. In most government departments and agencies, process of digitization involves the conversion of government information in term of text, photograph, map and etc that convert printed format to a digital format by using latest scanning technology equipment. Government information that has been scanned and digitized will be stored in a system to ensure it can be accessible to the public. Nowadays, most of the government information has been digitized, making it accessible and easier for people to locate information that they have right to know. Transformations toward digital governance become reality worldwide. Governments need to be aware and realize that digital of information government necessary to managed consistently in order to provide a basis for openness. Therefore government needs to begin to spend and invest in digital records management initiatives. Corydon Bjarne, Ganesan \& Martin (2016) was mention that through digitizing initiative, governments will be able to enhance public services, save money and enhance quality of life among citizens as well as expand their engagement with government.

Digitization policy and procedure manual are useful in order to support digitization initiatives of government information at all levels. It is useful as a guideline for digitization process, controls and tools (hardware and software). The policy and procedure manual will defend the integrity, authenticity, and security of the information once it open to the public. 
An observation regarding preservation and digitization of government information that was practice in Malaysia showed that archival and libraries institutions are doing well and move forward day by day in terms of developing and implementing sustainable preservation strategies and techniques such as allocation of specific funding, training for the staff and develop and enhance policies and procedure.

Although most government information and resources have transform in electronic format entities, the issues regarding preservation for tangible or printed government publications need to be focused in order to ensure it can accessible and useful for future generation.

d) Government information handle by Information Officer

The existence of Government Chief Information Officer ( $\mathrm{GClO}$ ) at MAMPU prove the Government's commitment to ensure the successfulness of coordination and the integration of all development projects regarding ICT and knowledge and information management in the public sector. GCIO and information professional have an important role to act as change agents through the alignment of the public sector strategic plan align with the national development plan.

A part from that, information professional in any agency in the government especially librarian, information system have showed that there are plays a big role in managing government information as a whole. Regarding the function of government information and the role of $\mathrm{GClO}$ and information professional (IP) in particular, it is important for information professional to to ensure information produced by government is worth saving and organize. Moreover, Faculty of Information Management under UiTM was introduced record management program to fill the shortage of records management professionals in the country because it will contribute more to the successfulness implementation of the electronic government initiative (Jamaludin, Norhayati \& Haliza (2018).

Edna, (1998) was mention that information professional become core players under MSC project initiative. They are responsible to empowering people especially among citizen especially government servant to become information literate that have skill in deal effectively with electronic information overload, create more valid local content, assess content critically as well as use web technologies.

\section{CONCLUSION}

Government information should be preserved not only as a legacy of public service knowledge but also as National knowledge heritage. This effort need to be main task in government daily operation in order to ensure that the public service become more competitive, high-value, competitive, creative and innovative to meet the people expectations who are always demanding more from government. Systematic management of electronic records and archives is crucial, not only for good governance, but also for bring up the ideals of a world civilization built upon prosperity, justice and peaceful for humanity as a whole. Government agencies need to act in accordance with the right policy formulated by the authority for the best practices to ensure that our nations 
INTERNATIONAL JOURNAL OF ACADEMIC RESEARCH IN BUSINESS AND SOCIAL SCIENCES Vol. 8, No. 9, Sept. 2018, E-ISSN: 2222-6990 @ 2018 HRMARS

corporate memory will be well manage in transparently, explicitly and comprehensively for future use. Systematic controls process is necessary in order to ensure effective electronic records management in order to support government information and official records. Basically, successfulness of record management system implementation mostly depends on NAM as the leading agency and support from all ministries, agencies, civil servants and public. Government information provide evidence for decision making, transparency and accountability that contribute to the economy growth and establishment of democratic governance. The government is accountable to its citizen and is the largest producer of vital national records.

\section{REFERENCES}

Arkib Negara Malaysia. (2018). Retrieved 31 May 2018 from: www.arkib.gov.my/c.

Corydon, B., Ganesan, V. \& Lundqvist, M. (2016). Digital by default: a guide to transforming government. McKinsey \& Company.

Reid, E. (1998). Malaysia's Multimedia super corridor and roles of information professionals. Proceedings of the IATUL Conferences. Paper 29. Retrieved 25 May 2018 from: http://docs.lib.purdue.edu/iatul/1998/papers/29.

Jamaludin, A., Hussin, N., \& Mokhtar, W. N. H. W. (2006). Library and information career in Malaysia:

aspirations of educators and the reality of the industry. In C. Khoo, D. Singh \& A.S. Chaudhry (Eds.), Proceedings of the Asia-Pacific Conference on Library \& Information Education \& Practice 2006 (A-LIEP2006), Singapore, 3-6 April 2006 (pp. 423-426). Singapore: School of Communication \& Information, Nanyang Technological University.

Ahmad, M. \& Othman, R. (2007). Implementation of electronic government in Malaysia: the status and potential for better service to the public. Public sector ICT management review, Oct 2006 - March 2007, Vol. 1 No.1. Retrieved 25 May 2018 from:

workspace.unpan.org/sites/Internet/Documents/UNPAN033295.pdf.

Yaacob, R.A. \& Sabai, R.M. (2011). Electronic Records Management in Malaysia: A Case Study in One Government Agency. Retrieved 31 May 2018 from: https://www.projectconsult.de/files/RM_Malaysia_SP_ERM11_420.pdf.

Shafie, S. (2018). e-Government Initiatives in Malaysia and the Role of the National Archives of Malaysia in Digital Records Management. Retrieved 31 May 2018 from: http://www.archives.go.jp/english/news/pdf/MrShaidin.pdf.

Jamil, S. (2007). Records management in government: the Malaysian experience. Retrieved 31 May 2018 from: https://doi.org/10.3828/comma.2007.3-4.13. 
INTERNATIONAL JOURNAL OF ACADEMIC RESEARCH IN BUSINESS AND SOCIAL SCIENCES

Vol. 8, No. 9, Sept. 2018, E-ISSN: 2222-6990 @ 2018 HRMARS

Lori, L.S. (2011). Introduction to government information resources. Retrieved 31 May 2018 from: https://www.southeastern.edu/library/directory/govdoc/pdf/introgovdoc.pdf.

Kootshabe, J. T. \& Mnjama, N. (2014). Preservation of government records in Botswana. Journal of the South African Society of Archivists, Vol. 47, p.26-49.

Mokhtar, U. A., \& Yusof, Z.M. (2009). Electronic records management in the Malaysian public sector: the existence of policy. Records Management Journal, Vol. 19 Issue: 3, p.231-244. Retrieved 31 May 2018 from: https://doi.org/10.1108/09565690910999201.

Unit Pemodenan Tadbiran dan Perancangan Pengurusan Malaysia. (2016). Retrieved 31 May 2018 from: http://www.mampu.gov.my/ms/. 